\title{
A Comparative Analysis of Health Indicators of Nigeria and Rwanda: A Nigerian Volunteer's Perspective
}

\author{
Joshua Istifanus Anekoson* \\ School of Public Health, National University of Rwanda, Butare, Rwanda \\ *Corresponding author: dristifanus@yahoo.com
}

Received June 20, 2013; Revised August 10, 2013; Accepted August 13, 2013

\begin{abstract}
Background: Nigeria and Rwanda are both developing countries located in Sub-Saharan Africa. They are differently endowed with natural and human resources but what does that translates into in terms of health care? This study aimed at a critical comparative analysis of selected health indicators of Nigeria and Rwanda(a country ravaged by genocide 16 years ago). Materials and Methods: I performed MEDLINE and bibliographic searches for English-language studies relevant to health indicators of Nigeria and Rwanda, including a search of non-indexed local journals. Personal observation and experience as Nigerian Technical Aid Corp Volunteer in Rwanda from May 2005 to May 2007 was also used. The information obtained included: demographic and socioeconomic data, mortality statistics, selected burden of diseases, health service coverage, risk factors for some diseases, health system resources and health expenditure of Nigeria and Rwanda. Results: The findings showed that most of the health indicators such as poverty index, life expectancy, child mortalities, immunisation coverage, contraceptive prevalence, access to improved drinking water, tuberculosis treatment success, hospital beds per population, among others of Rwanda are better than that of Nigeria despite the huge human and natural resources Nigeria is endowed with. Conclusion: There is need for concerted effort at the Federal, State and Local levels in Nigeria to harness the human and natural resources of the nations to improve on the health status of the people, and this should bemulti-sectoral, multi-dimensional and disciplinary in nature.
\end{abstract}

Keywords: health indicators, Nigeria, Rwanda, volunteer's experience

Cite This Article: Joshua Istifanus Anekoson, "A Comparative Analysis of Health Indicators of Nigeria and Rwanda: A Nigerian Volunteer's Perspective.” American Journal of Public Health Research 1, no. 7 (2013): 177182. doi: 10.12691/ajphr-1-7-6.

\section{Introduction}

\subsection{An overview of Nigeria}

Nigeria has an estimated population of about 148 million people -nearly one quarter of Sub-Saharan Africa's (SSA's) population and it is bordered by the Gulf of Guinea, Cameroon, Benin, Niger and Chad (Figure 1). The country has more than 200 ethnic groups, with three major tribes, Ibo (East), the Hausa (North), and the Yoruba (West) [1-6].

Agriculture is the dominant economic activity in terms of employment and linkages with the rest of the economy. Roughly $75 \%$ of Nigeria's land is arable, of which about $40 \%$ is cultivated. The United Nations Food and Agriculture Organisation rates the productivity of Nigeria's farmland as low to medium but with medium to good productivity if properly managed. Despite two major rivers, the Niger and the Benue, agriculture is predominantly rain fed. Yams, cassava, rice, maize, sorghum, and millet constitute the main food crops. The principal export crops are cocoa and rubber, which together account for nearly $60 \%$ of non-oil merchandise exports and Nigeria has per capita Gross National Products (GNP) of US\$ $564[1,7,8]$.

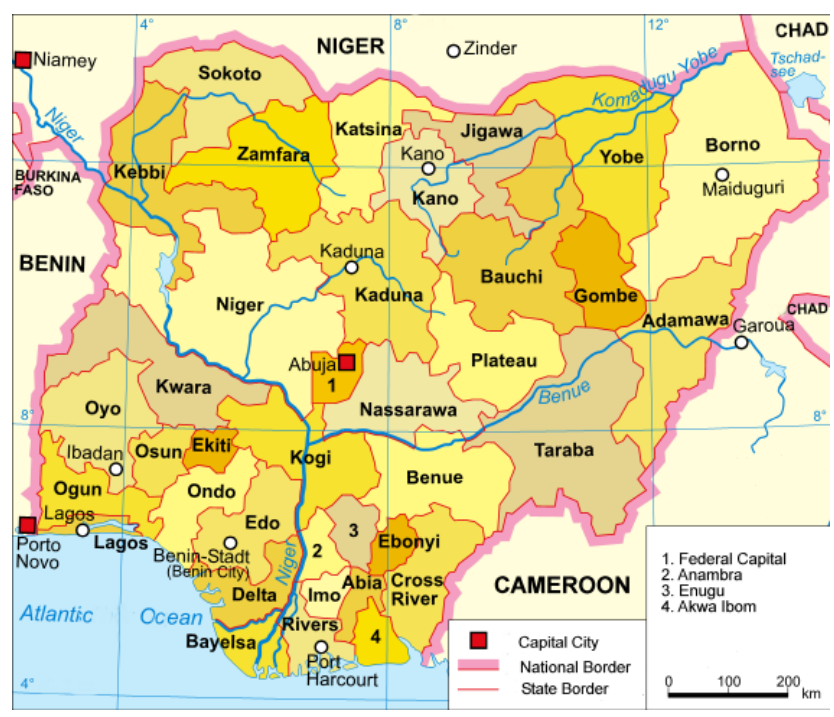

Figure 1. Map of Nigeria

Nigeria has estimated proven oil reserves of 32 billion barrels; it is the $6^{\text {th }}$ largest producer in Organisation of Petroleum Exporting Countries(OPEC). At the current rate 
of production, these reserves are sufficient to last about 37years.Proven natural gas reserves are estimated at 174 trillion cubic feet, with energy content slightly greater than the country's oil reserves. At present levels, these reserves will last 110years [1].

The country is also blessed with abundant solid mineral deposits, including coal, tin ore, kaolin, gypsum, columbite, gold, gemstones, barites, graphite, marble, tantalite, uranium, salt, soda, and sulphur.

Nigeria has about 104 universities (federal, state and private) and boasts an educated labour force; it also has a large domestic market, which could serve as a springboard for entering export markets [1,3].

\subsection{An Overview of Rwanda}

Rwanda is a small, densely populated landlocked country in east central Africa bordered by Uganda, Burundi, Tanzania and Democratic republic of Congo (DRC) (Figure 2) and has a population of 9.5 million people. Rwanda ranks among the poorest countries in the world with per capita GNP of US\$ 230. It is a densely populated, poor rural country, with few natural resources and industries. Agriculture is the mainstay of the economy with about $90 \%$ of the population engaged in subsistence agriculture [2,5]. The agricultural products include coffee, tea (which are primary foreign exchange earners), pyrethrum (insecticide made from chrysanthemums), bananas, beans, sorghum, potatoes; livestock while the export commodities are coffee, tea, hides, tin ore. Agribusiness accounts for $36.2 \%$ of Rwanda's Gross Domestic Products (GDP) and $40.2 \%$ of exports. It has few natural resources to exploit and a small uncompetitive industrial sector. Natural resources are gold, cassiterite (tin ore), wolframite (tungsten ore), methane, hydropower, arable land.

Minerals in 2007 accounted for 35.9\% of export earnings, followed by tourism, tea and coffee, and pyrethrum (whose extract is used in insect repellent). Mountain gorillas and other upscale eco-tourism venues are increasingly important sources of tourism revenue $[2,9,10,11]$.

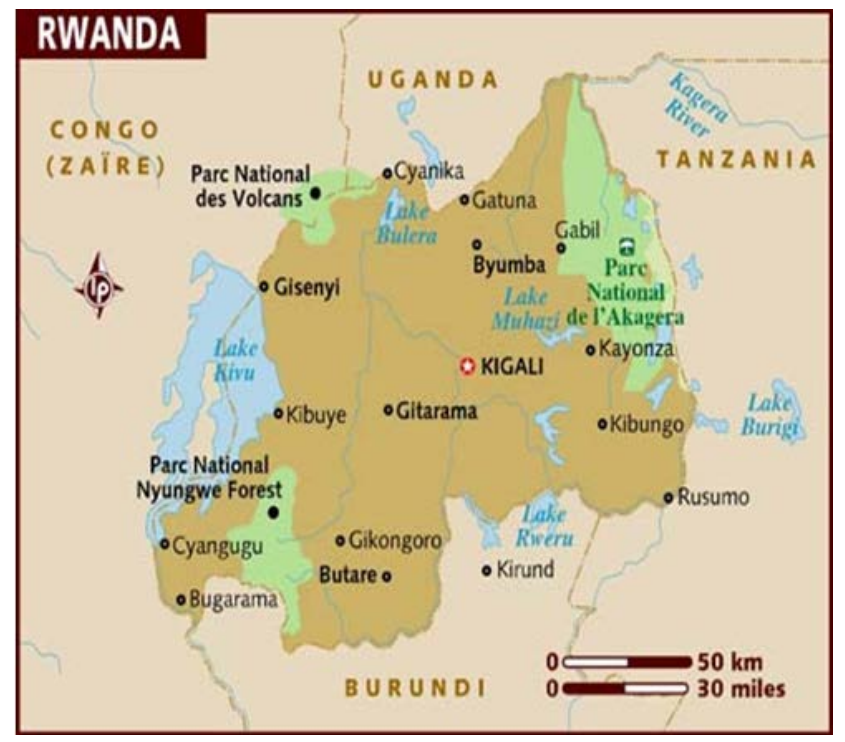

Figure 2. Map of Rwanda
The 1994 genocide decimated Rwanda's fragile economic base, severely impoverished the population, particularly women, and eroded the country's ability to attract private and external investment. Despite Rwanda's fertile ecosystem, food production is not keeping pace with population growth; thus, food imports are the norm. Rwanda continues to receive substantial aid money and obtained International Monetary Fund (IMF)-World Bank Heavily Indebted Poor Country (HIPC) initiative debt relief in 2005-06of US\$ 1.89 billion. [7,8,9] Rwanda also received Millennium Challenge Account Threshold status in 2006. The government has embraced an expansionary fiscal policy to reduce poverty by improving education, infrastructure, and foreign and domestic investment and pursuing market-oriented reforms, although energy shortages, instability in neighbouring states, and lack of adequate transportation linkages to other countries continue to handicap growth.

This study aimed at a critical comparative analysis of the health indicators of Nigeria and Rwanda and also discusses personal experience as a Nigerian Volunteer in Rwanda.

\section{Materials and Methods}

MEDLINE and bibliographic searches for Englishlanguage studies relevant to health indicators of Nigeria and Rwanda, including a search of non-indexed local journals was carried out between 2007 and 2010.

Personal observation and experience as Nigerian Technical Aid Corp Volunteer in Rwanda from May 2005 to May 2007 was also used.

The information used in the comparative analysis included demographic and socioeconomic data, mortality statistics, selected burden of diseases, health service coverage, risk factors for some diseases, health system resources and health expenditure of the 2 countries, and emphasis was made on the similarities and differences and the possible explanations.

\section{Results}

\begin{tabular}{ccc}
\multicolumn{3}{c}{ Table 1. Demographic and socioeconomic statistics } \\
\hline Indicator & Nigeria & Rwanda \\
\hline $\begin{array}{c}\text { Year of Independence } \\
\text { Annual population growth rate } \\
\text { (\%) (1997-2007) }\end{array}$ & 1960 & 1962 \\
$\begin{array}{c}\text { Africa regional average- 2.5 } \\
\text { Total fertility rate per woman } \\
\quad \begin{array}{c}\text { (2007) } \\
\text { Adult literacy rate (\%) } \\
\quad(2000-2007)\end{array}\end{array}$ & 2.5 & 4.2 \\
$\begin{array}{c}\text { Population living (\%) < US\$1 } \\
\text { per day (2000-2006) }\end{array}$ & 5.4 & 5.9 \\
$\begin{array}{c}\text { Net primary school enrolment } \\
\text { ratio }\end{array}$ & 62.4 & 64.9 \\
$\quad$ (2000-2007) & $68(\mathrm{~m})$ & 74.6 \\
\hline
\end{tabular}

Source: WHO, World Health Statistics, 2009

Nigeria got her independence in 1960, 2 years before Rwanda. While the annual growth rate is almost twice that of Nigeria the total fertility and adult literacy rates were similar in both countries. The net primary school enrolment ratio for both male and female are higher in Rwanda (Table 1). 
Table 2. Mortality statistics

\begin{tabular}{ccc}
\hline Indicator & Nigeria & Rwanda \\
\hline Life Expectancy (Years) at birth & $48(\mathrm{~m})$ & $49(\mathrm{~m})$ \\
(2007) & $50(\mathrm{f})$ & $51(\mathrm{f})$ \\
Africa regional average- 52 & $49(\mathrm{both})$ & $50(\mathrm{both})$ \\
Infant Mortality (per 1000 live births) & $103(\mathrm{~m})$ & $113(\mathrm{~m})$ \\
(2007) & $91(\mathrm{f})$ & $105(\mathrm{f})$ \\
Africa regional average-88 & $97(\mathrm{both})$ & $109(\mathrm{both})$ \\
(2007) & $193(\mathrm{~m})$ & $185(\mathrm{~m})$ \\
Ander five Mortality (Per 1000 live births) & $184(\mathrm{f})$ & $176(\mathrm{f})$ \\
Maternal Mortality ratio per 100,000 live & $189(\mathrm{both})$ & $181(\mathrm{both})$ \\
births & 1100 & 1300 \\
Africa regional average-900 & 156 & 59 \\
Africa regional average-104 & & \\
Malaria mortality rate 100,000 population & & \\
Source: WHO, World Health Statistics, 2009 & \\
Life expectancy, under 5 and malaria mortality of \\
Rwanda are better than that of Nigeria. However, the \\
maternal mortality ratio, infant mortality are better than \\
that of Rwanda (Table 2).
\end{tabular}

Table 3. Some selected burden of diseases

\begin{tabular}{ccc}
\multicolumn{3}{c}{ Table 3. Some selected burden of diseases } \\
\hline Indicator & Nigeria & Rwanda \\
\hline $\begin{array}{c}\text { Prevalence of TB } \\
\text { Per 100,000 population (2007) }\end{array}$ & 521 & 590 \\
$\begin{array}{c}\text { Prevalence of HIV among Adults age } \geq 15 \text { years } \\
\text { Per 100,000 population } \\
\quad \begin{array}{l}\text { (2007) } \\
\text { Africa regional average-4735 }\end{array}\end{array}$ & 2886 & 2342 \\
$\begin{array}{c}\text { Number of confirmed poliomyelitis cases 2001 } \\
\text { Number of reported polio in 2007 }\end{array}$ & 56 & 0 \\
\hline
\end{tabular}

Source: WHO, World Health Statistics, 2009

Tuberculosis prevalence in the two countries are similar and the prevalence of HIV among adults $\geq 15$ years are high in both Nigeria and Rwanda but below the Africa regional average of 4735. No case of confirmed poliomyelitis has been reported in Rwanda since 2001 unlike in Nigeria (Table 3).

Table 4. Some selected Health service coverage Indicator Nigeria Rwanda

Ante-Natal care coverage (\%)

at least 1 visits (Africa regional average-73)

at least 4 visits (Africa regional average-45) 2000-2008

$58 \quad 96$

Births attended by skilled health Personnel (\%) 2000-2008

Africa regional average-46

Immunization coverage among one year old (\%)

DTP3(Africa regional average-74)

Measles(Africa regional average-74) 2007

Tetanus protection for Neonates at birth (\%) (2007)

Africa regional average-31

Contraceptive prevalence (\%) 2000-2006

Africa regional average-24.4

ART coverage among people with advanced HIV infection (\%)

2007(Africa regional average-30) PMTCT

TB detection rate under DOTS (\%)(2007)

Africa regional average-47

TB RX success under DOTS (\%) (2006)

Africa regional average-75

Children aged 6-59 months who received Vitamin

A supplementation (\%) (2000-2007) Africa regional average-47.9

Children aged $<$ 5years sleeping under IT mosquito bed nets (\%) 2000-2007 Africa regional average-14
Antenatal coverage (atleast 1 visit), births attended by skilled health personnel, immunization coverage among one year (for DPT3 and measles), tetanus protection for neonates at birth, contraceptive prevalence, ART coverage among people with advanced HIV infection, TB detection rate under DOTS, TB treatment under DOTS, children aged 6- 59 months who received vitamin A supplementation and children aged $<5$ years sleeping under IT mosquito bed nets are all better in Rwanda than Nigeria (Table 4).

\begin{tabular}{ccc}
\multicolumn{3}{c}{ Table 5. Risk factors } \\
\hline Indicator & Nigeria & Rwanda \\
\hline Access to improved drinking water sources (\%) & 65(urban) & 82(urban) \\
(2006) & 30(rural) & 61(rural) \\
Africa regional average-59 & 47(total) & 65(total) \\
Access to improved sanitation (\%) & 35(urban) & 34(urban) \\
(2006) & 25(rural) & 20(rural) \\
Africa regional average-33 & 30(total) & 23(total)
\end{tabular}

Low birth weight Newborns (\%)(2000-2006) Africa regional average-14

$14 \quad 6$

Infants exclusively breast fed for the first 6 months of life (\%) (2000-2008)

Africa regional average-29.5

Children aged $<$ 5years underweight for age (\%)

$$
\text { (2000-2007) }
$$

Proportion of males aged 15-24 years with comprehensive correct knowledge of HIV/AIDS (\%)

Africa regional average-30

Proportion of females aged 15-24 years with comprehensive correct knowledge of HIV/AIDS (\%)

Africa regional average-23

\section{Source: WHO, World Health Statistics, 2009}

Access to improved drinking water sources in Rwanda is better and above African average of $59 \%$ while accesses to improved sanitation are below African average in both Rwanda and Nigeria. Statistics on Low birth weight newborns, infants exclusively breast fed for the first 6 months of life, children aged $<5$ years underweight, proportion of males and females aged 15- 25 years with comprehensive correct knowledge of HIV/AIDS are better in Rwanda than Nigeria (Table 5).

Table 6. Health workforce and infrastructure

\begin{tabular}{|c|c|c|c|c|}
\hline Indicator & \multicolumn{2}{|c|}{ Nigeria } & \multicolumn{2}{|c|}{ Rwanda } \\
\hline $\begin{array}{l}\text { No of Physicians \& density } \\
\text { per } 10,000 \text { population }\end{array}$ & No & Density & No & Density \\
\hline $2000-2007$ & 34,923 & 3 & 432 & $<1$ \\
\hline $\begin{array}{c}\text { No of Nursing \& Midwifery } \\
\text { personnel \& density per } \\
10,000 \text { population } 2000- \\
2007\end{array}$ & 210,306 & 17 & 3647 & 4 \\
\hline $\begin{array}{c}\text { No of dentistry personnel \& } \\
\text { density per } 10,000 \\
\text { Population } 2000-2007\end{array}$ & 2482 & $<1$ & 21 & $<1$ \\
\hline $\begin{array}{l}\text { No of pharmaceutical } \\
\text { personnel \& density }\end{array}$ & 6344 & $<1$ & 278 & $<1$ \\
\hline $\begin{array}{l}\text { No of community \& } \\
\text { traditional health workers \& } \\
\text { density per } 10,000 \\
\text { population } 2000-2006\end{array}$ & 115,761 & 9 & 12,000 & 14 \\
\hline $\begin{array}{l}\text { No of laboratory health } \\
\text { workers \& density per } \\
10,000 \text { population } 2000-06 \\
\text { Hospital beds per } 10,000\end{array}$ & 690 & $<1$ & 39 & $<1$ \\
\hline $\begin{array}{l}\text { Population } \\
2008\end{array}$ & 5 & & 16 & \\
\hline
\end{tabular}


The ratios of physicians and nursing/midwifery personnel per 10,000 populations are better in Nigeria compared to that of Rwanda. However, the ratios of dentistry personnel, pharmaceutical personnel and laboratory health workers per 10,000 populations are same in both Nigeria and Rwanda. Hospital beds and ratio of community and traditional health workers per 10,000 populations are better in Rwanda than Nigeria (Table 6).

Table 7. Health expenditure

\begin{tabular}{|c|c|c|}
\hline Indicator & Nigeria & $\begin{array}{c}\text { RwandaAfricaregional } \\
\text { average } \\
\end{array}$ \\
\hline $\begin{array}{l}\text { Total expenditure on health as } \\
\text { a \% GDP }\end{array}$ & $\begin{array}{l}5.0(2000) \\
3.8(2006)\end{array}$ & $\begin{array}{c}4.2(2000) 5.5 \\
10.9(2006) 5.5\end{array}$ \\
\hline $\begin{array}{l}\text { General government health } \\
\text { expenditure as a \% of total } \\
\text { expenditure on health }\end{array}$ & $\begin{array}{l}33.5(2000) \\
29.7(2006)\end{array}$ & $\begin{array}{l}39.2(2000) 44.8 \\
42.5(2006) 47.1\end{array}$ \\
\hline $\begin{array}{c}\text { General government } \\
\text { expenditure on health as a \% } \\
\text { of total government } \\
\text { expenditure }\end{array}$ & $\begin{array}{l}4.2(2000) \\
3.5(2006)\end{array}$ & $\begin{array}{c}8.2(2000) 8.2 \\
18.8(2006) 8.7\end{array}$ \\
\hline $\begin{array}{c}\text { Social security expenditure on } \\
\text { health as a \% general } \\
\text { government expenditure on } \\
\text { health }\end{array}$ & $\begin{array}{l}0.0(2000) \\
0.0(2006)\end{array}$ & $\begin{array}{l}6.4(2000) 8.2 \\
4.1(2006) 7.6\end{array}$ \\
\hline $\begin{array}{l}\text { Out-of-pocket expenditure as } \\
\text { a \% of private expenditure on } \\
\text { health }\end{array}$ & $\begin{array}{l}92.7(2000) \\
90.4(2006)\end{array}$ & $\begin{array}{l}40.7(2000) 55.9 \\
38.6(2006) 49.8\end{array}$ \\
\hline
\end{tabular}

Source: WHO, World Health Statistics, 2009

The total expenditure on health as a \% GDP in both countries are below the African regional average of $5.5 \%$. However, it has increased from $4.2 \%$ to $10.9 \%$ (2006) in Rwanda but decreased in Nigeria from $5.0 \%$ to $3.8 \%$ (2006).The general government expenditure on health as a \% of total government expenditure are below average in both countries but that of Rwanda has been increasing while that of Nigeria decreasing. General government expenditure on health as a total government expenditure has increased from $8.2 \%$ to $18.8 \%$ in Rwanda while in Nigeria it decreased from $4.2 \%$ to $3.5 \%$ far below the African average of $8.7 \%$. Social security expenditure on health as a general government expenditure on health are poor in both countries, but the use of out-of-pocket expenditure as a \% of private expenditure is very high in Nigeria (90.4\%) and low in Rwanda (38.6 \%) (Table 7).

\section{Discussion}

Nigeria and Rwanda virtually got their independence about the same time. However, the total fertility, annual population growth rates of Rwanda are higher than that of Nigeria that could be as a result of the 1994 genocide whereby some families were almost wiped out. The reason for the high total fertility and annual population growth rates is to make up for the deaths of families as during participant observation while in Rwanda. The net primary school enrolment ratio is also better than that of Nigeria for both male and female. Education in Rwanda is virtually compulsory and the good policy monitoring and implementation. However, the system of education is promotional in nature whereby student cannot fail an examination. This may be responsible for the slightly low standard of education when compared to Nigeria.

Poverty is an important factor which affects health care in any nation $[7,12]$. However, despite the huge natural resources in Nigeria, the poverty rate is still high. Available data suggests that in general, the more the wealth of a nation, the better the indices of health status of its citizenry [3]. This fact then raises the concern for the linkages between poverty and ill-health and the need to alleviate poverty as a strategy for improved health [3]. People living under extreme poverty typically lack access to safe drinking water, decent housing, adequate sanitation, food, education, professional health care, transportation, safe and secure employment and health information, among others $[13,14]$.

Some of the factors that are responsible for high poverty rate in Nigeria compared to Rwanda include high level of corruption, inadequate infrastructures such as electricity, huge amount of federal government budget usually spent on governance by the political office holders $[1,3,6,15]$.

Life expectancy at birth of the 2 countries are similar and factors such as high prevalence of communicable diseases such as tuberculosis, malaria, HIV and AIDS, deaths associated with pregnancy and child birth play important role in this picture. However, the malaria mortality rate in Rwanda is about half that of Nigeria. Some of the reasons for this include effective environmental control, strict non-dispensing of drugs without prescription, sell of ACT drugs with only positive malaria result to prevent development of resistance, low problems of fake and adulterated drugs. Poliomyelitis has never been reported in Rwanda since 2001.DPT3 among children of one year, measles immunization and tetanus protection for neonates at birth are far above the Africa average in Rwanda which is not the case in Nigeria. In Nigeria, poliomyelitis is a public health issue and some of the reasons for parents not taking their children for immunisation include cultural and religious factors, misinformation that the vaccine contains anti-fertility agents, among others. Infant and under 5 mortalities are above Africa average (88 and 145 per 1000 live births respectively) in both countries.

The level of maternal mortality in Africa is estimated at 100 to 200 fold that of the developed countries, and developed countries with $11 \%$ of all births has less than $1 \%$ of total maternal deaths $[5,16]$.

Nigeria is said to account for $10 \%$ of the world's maternal mortality, being among the highest in the world despite resources being taken to improve maternal health $[13,15]$. The figures are very high in Nigeria and similar to that of Rwanda. Similarly, the life time risk of maternal death in Nigeria is 1 in 13 [17]. These unacceptable high maternal mortality and morbidity in Nigeria are due to a variety of reasons including non-availability of health care services especially in rural areas, socio-economic factors, poor utilization of maternal health care services due to geographical, economic and cultural inaccessibility, harmful traditional practices such as early child marriage and female genital mutilation [18,19].

Malaria, HIV/AIDS and tuberculosis in sub-Saharan Africa are diseases of public health importance and they continue to weaken the public health services. Malaria presents enormous health problems in Africa; of the 300400 million acute attacks that occur globally each year, about $80 \%$ of the cases and deaths occur in Tropical Africa [22]. Malaria is the most common cause of outpatient visits to health facilities and it is reported as one of the leading causes of death [23] and it is a leading cause of 
morbidity and mortality in the country. Available record show that at least $50 \%$ of the population of Nigeria suffers from at least one episode of malaria each year and malaria accounts for $45 \%$ of all out-patient visit [24]. More than 2 billion cases of tuberculosis are recorded worldwide (1/3 of the world's population); [25] 250-300,000 cases are reported in Nigeria and $50 \%$ are smear positive. [26] Nigeria is $4^{\text {th }}$ in the world in term of total cases of TB in 2007. [27] A number of factors play important role in Nigeria for the high cases of these diseases. These include: low level of use of insecticide treated net (ITN), poor environmental conditions that allows mosquitoes to breed, lack of use of personal protective measures, poor inspection of the environment by sanitary inspectors among others. In the case of TB, the issues are ignorance about the disease, poor access to treatment due to poverty (despite the fact that the drugs are free), poor contact tracing, people defaulting from treatment, ingestion of unpasteurized cow milk, drug resistance and co-infection with HIV/AIDS. High level of stigma and discrimination against persons carrying HIV, poor access to antiretroviral drugs (ARV) and fear of testing and poor premarriage screening among others, are important in the spread of HIV/AIDS in Nigeria.

The burden of these diseases is lower in Rwanda than in Nigeria. In Rwanda, stigmatization and discrimination against people living with HIV/AIDS is almost nonexistent, there are wide spread (decentralized) treatment centres in both rural and urban areas. Active TB contact tracing is more serious in Rwanda than Nigeria which is a plus for the control of TB, and polythene bags are banned (only paper bags are allowed) because they are not environment friendly and they can serve as breeding place for mosquitoes and rodents.

Other factors that help in the better health indicators in Rwanda include better access to potable drinking water and low prevalence of low birth weight newborn, better ratio of hospital beds per population, political commitment by the government and effective National Health Insurance Scheme among others.

Access to drinking water and sanitation and prevalence of low birth weight newborn are important indicators of socio-economic development of a Nation. About $80 \%$ of diseases in Africa are related to water and globally an estimated 1.7 million people die annually from diseases linked to unsafe water, sanitation and hygiene. [28] Despite the terrible topography and poor economic status of Rwanda (classified as Heavily indebted poor country by IMF), Rwandans have better access to drinking water than Nigerians. The prevalence of low birth weight newborn is higher in Nigeria and it is important to know that there is inverse relationship between low birth weight and infant mortality. Other factors that influence child survival include growth monitoring, oral rehydration therapy, breast feeding, female education, family planning and food supplementation.

One major impediment to health development in Nigeria remains the weakness of political commitment to the objectives of the national health policy and inadequate budget to the health sector .Thus while government declares its acceptance of PHC as a strategy to achieve health for all Nigerians; it fails to fully implement the basic principles of this strategy. Budgetary allocation to health falls very short of the $15 \%$ recommended by WHO.
Also mechanisms for regular policy monitoring and evaluation have not been whole heartedly constituted.

Heath resources are usually mal-distributed in Nigeria to the disadvantage of the large rural dwellers. Highly skilled health personnel are usually concentrated in the urban areas where there are better social and recreational facilities. There are instances whereby referred cases gets to reference hospitals in urban areas very late due to poor road network, lack of vehicles or other logistics $[18,19]$.

There is also inefficient use of resources for health. There is evidence that the problem of poor health status and inadequate health services to the people are not all due to inadequate allocation of resources to health, but are also due to glaring allocationinefficiency within the health sector. This situation is worse off in Nigeria than in Rwanda. There is hardly resources wastage in Rwanda, for the 2 years I have spent here I have not seen any government project that was abandoned after commencement!

In fact, a Permanent Secretary in the Rwanda Ministry of Health was once arrested and detained because of issue of fake and adulterated drugs importation.

Weak referral system that is in most cases not 2-way in Nigeria has succeeded in keeping facilities grossly underutilized. The tertiary and secondary health care institutions consume a disproportionate share of public health expenditure whereas most of the conditions that affect the majority of Nigerians can be managed at the primary health care. This allocation inefficiency may mean that common conditions will either not receive treatment or will receive treatment at unnecessary high costs. Poor referral system also leads to unnecessary crowding of the secondary and the tertiary health care institutions with cases that are ordinarily for treatment at primary health care centre thereby causing delay in the attention to cases that are for secondary and tertiary health care institutions. The result of this is high cost of treatment arising from highly skilled personnel deployed to manage simple conditions that could otherwise be managed by lower level staff [3].

The referral system in Rwanda is effective, organized and 2-way which helps in the quality of health care services there.

Resources spent on health plays important role in the quality of health and health status of the people. The total expenditure on health as a \% of GDP in Nigeria is below the African average of $5.5 \%$ but that of Rwanda is about thrice that of Nigeria. However, the general government health expenditure as a \% of total expenditure on health are both below the regional average in both countries even that of Rwanda slightly better. General government expenditure as a \% of total government expenditure has been on the increase in Rwanda while in Nigeria it has been on the decrease.

There is inverse relationship between access to health and quality of health care and out-of-pocket expenditure.

Social security in expenditure on health as a \% general government expenditure on health is zero in Nigeria, it is $6.4 \%$ (2000) and $4.1 \%$ (2006) in Rwanda, slightly lower than the average for Africa.

Indicator of out-of-pocket expenditure as a \% of private expenditure on health is not encouraging in Nigeria. The better situation in Rwanda is an indication of government political will and commitment and collaboration with private partners to fund health there. Both countries need 
to increase their budgetary allocation to health as a \% of GDP to meet the $15 \%$ recommended by the WHO, but Nigeria need to do more.

\section{Conclusion}

Nigeria with vast human and material resources (the $6^{\text {th }}$ world largest producer of petroleum in the world) does not have a better health indicators compared to Rwanda, which is a war torn, poor, landlocked country with almost no natural resources.

There is need for Nigeria to utilize the various opportunities it has such as huge human and material resources, a good number of training and research institutes, primary, secondary and tertiary health institutions, national health insurance scheme (NHIS) and an abundant national youth service corps (professionals) among others to improve the health status of the people. This should be multi-disciplinary in approach.

Rwanda on the other hand should improve the quality of it education, control socio-cultural factors such as open spitting that aids in the spread of TB. There is also need to empower the citizens and alleviate poverty, train more health staff, maintain the tempo in the control of poliomyelitis among others.

\section{References}

[1] National Economic Empowerment and Development Strategy (NEEDS), Nigeria, 2004

[2] Central Intelligence Agency (CIA), The world fact book 2008

[3] Osibogun, A. Crises and challenges in the Nigerian health sector. Nigerian journal of community medicine and primary health care, 2004, 16(2):1-7.

[4] Osibogun, A. Health as a strategic weapon against poverty. Nigerian journal of community medicine and primary health care, 2003, 16(2):1-7.

[5] WHO,World health Statistics 2009.

[6] Sabitu, K. The evolution of human resource management in reforming the health sector in Nigeria. Annals of Nigerian Medicine, 2006, 2(2):1-8.

[7] WHO .Macroeconomics and health: Investing in health for economic development. Report of the Commission on macro economies and health. Geneva, WHO 2001; 23-24.

[8] Deepa N and Patti P.Nigeria: ill-being and insecurity.Voices of the poor from many lands. The World Bank, 2002; 85-112.

[9] Bureau of African Affairs, February 2008.
[10] Pia S, Francois D and Charlotte L.Pilot testing pre-payment for Health Services in Rwanda : Results and Recommendations for Policy Directions and Implementations. Partnerships for Health Reform, Technical Report No 66, 2001:1-95.

[11] Rwanda Investment and Export Promotion Agency (RIEPA) Newsletter, 2008.

[12] World health organisation (WHO).Coordinated health and human resources development. Report of WHO Study Group. Technical report series 801, 1990a. Geneva: WHO.

[13] Grant, J.P. State of the world's children, New York: Oxford University Press 1992.

[14] Martineau, T and Buchan, J. Human resources and the success of health sector reform. Human Resources for Health Development journal, 2000; 4(3):100-110.

[15] FOS/NDHS, Federal office of Statistics and Institute for Resource Development/ macro international, Nigeria Demographic and Health Survey 1990, Lagos : Federal office of Statistics and Columbia: MD Institute for Resource development/ macro international. 1992: 211-215.

[16] Rosenfield A and Maine, D. Maternal mortality: a neglected Tragedy: where is the ' $\mathrm{M}$ ' in MCH? Lancet 1985, ii: 83-85.

[17] Russel,A. Making pregnancy and child bearing safer for women in West Africa, Carnegie Quarterly, 1993,XXXVIII (1): 2-16.

[18] Joshua, IA. A critical evaluation of women and gender based issues in Nigeria: A public health perspective. Zaria journal of social sciences, 2008; 1(1):82-96.

[19] Joshua, IA. (2008).Politics, Health \& Military Diplomacy: A Critical Review. Annals of Nigerian Medicine, 2008; 3(1):1-9.

[20] Odutola, A. Brain drain. Africa Health, 2004, issue 10: 3.

[21] Ofili, AN; Asuzu, MC; Obgeide, O.Causes of Job dissatisfaction among nurses in a Nigerian Teaching Hospital. Nigerian journal of community medicine and primary health care, 2003, 15(1):4452.

[22] WHO. Practical chemotherapy of malaria. Report of scientific group. Technical Report Series .1998; No.981.

[23] UNICEF. Childhood under threat. The State of the world's children. United Nation Children Fund, Geneva.2006; 118.

[24] Federal Ministry of Health (FMOH). National Strategic Plan for Roll Back Malaria in Nigeria 2001 - Abuja; Federal Ministry of Health, Nigeria; 2001.

[25] Lonnroth, K. and Ravighone, M. Global epidemiology of Tuberculosis: Prospects for control. SeminRespirCrit Care med. 2008; 29:481.

[26] FMOH. Modules for the Training of Health facility workers in TB control. NTBLCP $3^{\text {rd }}$ ED.2008; 5.

[27] 27. WHO. Global tuberculosis control - epidemiology, strategy and financing. WHO Report 2009. WHO/HTM/TB/2009. www.who.int/tb/publications/global_ report/2009/en/index.html. (Assessed 20/01/09).

[28] WHO. Coverage of Maternal Care. A listing of available information .Maternal and Newborn Health /Safer motherhood (Document WHO/RHT/MSM/96.28).Geneva, Switzerland: WHO 1997. 